\title{
THE VAUGHAN LEWIS GLACIER, JUNEAU ICEFIELD, ALASKA
}

The Vaughan Lewis Glacier is one of the more striking glaciers in the Juneau Icefield of Alaska. It lies in lat. $58^{\circ} 50^{\prime}$ N., long. $134^{\circ} \mathrm{I} 7^{\prime}$ W., at the head of a great canyon extending 30 miles $(48 \mathrm{~km}$.) inland from the northern end of Alaska's "inside passage", about 36 miles (58 km.) north-north-east of the town of Juneau (Fig. I); the glacier trends generally north-

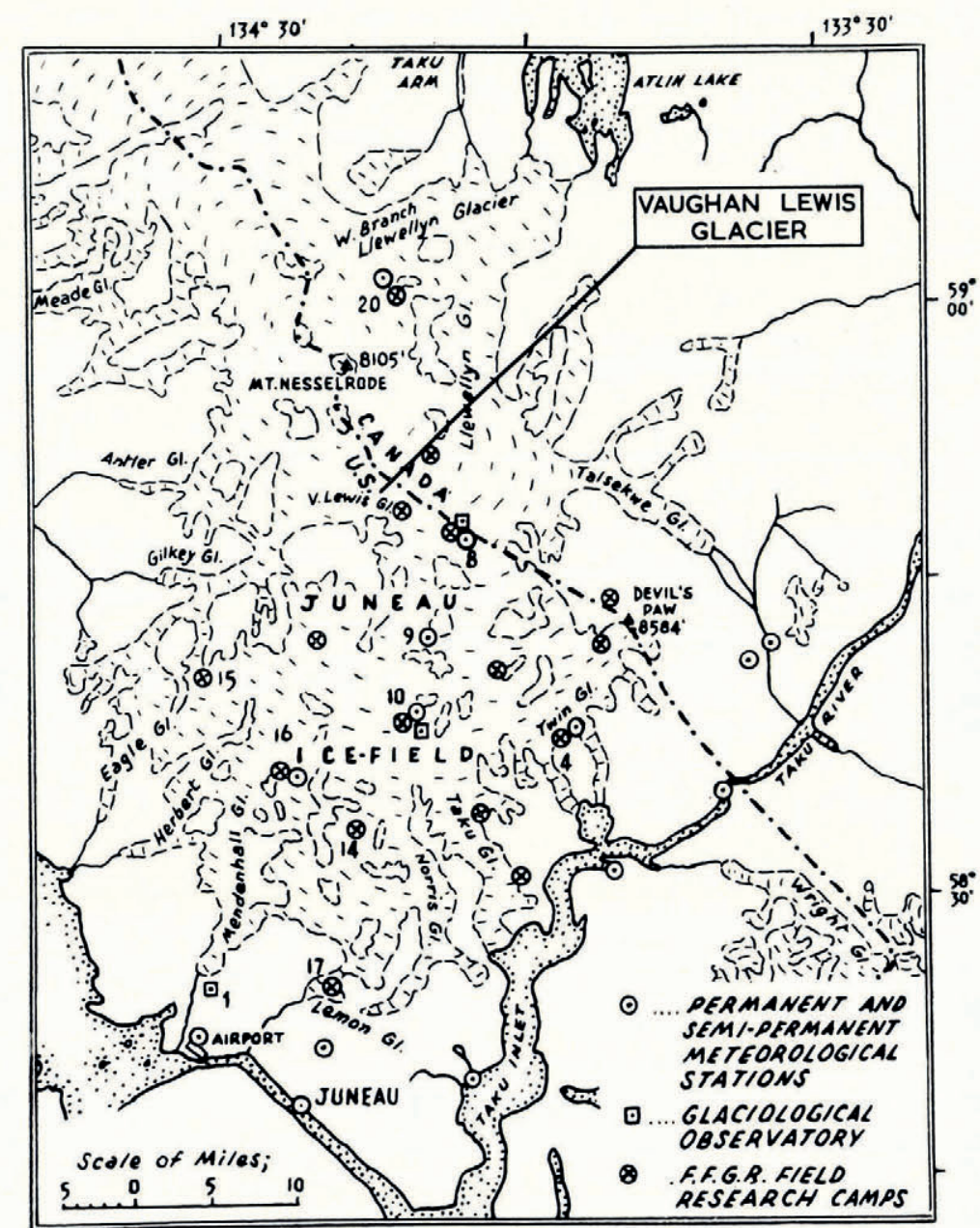

Fig. I. Sketch map of the Juneau Icefield and vicinity showing the situation of the Vaughan Lewis Glacier south of Mount Nesselrode and near the boundary between Alaska and Canada. (By courtesy of Maynard M. Miller)

westward for approximately 3.5 miles $(5.6 \mathrm{~km}$.) to an ice fall where it joins the Gilkey Glacier.

This glacier is remarkable for the magnificent Forbes-type bands displayed on its surface (Fig. 2), and these are considered to be the finest in Alaska. It is fed by the highest major névé on the Juneau Icefield (technically, in the Alaska-Canada Boundary Range), and in its vicinity are the main northern research facilities of the Juneau Icefield Research Program. 


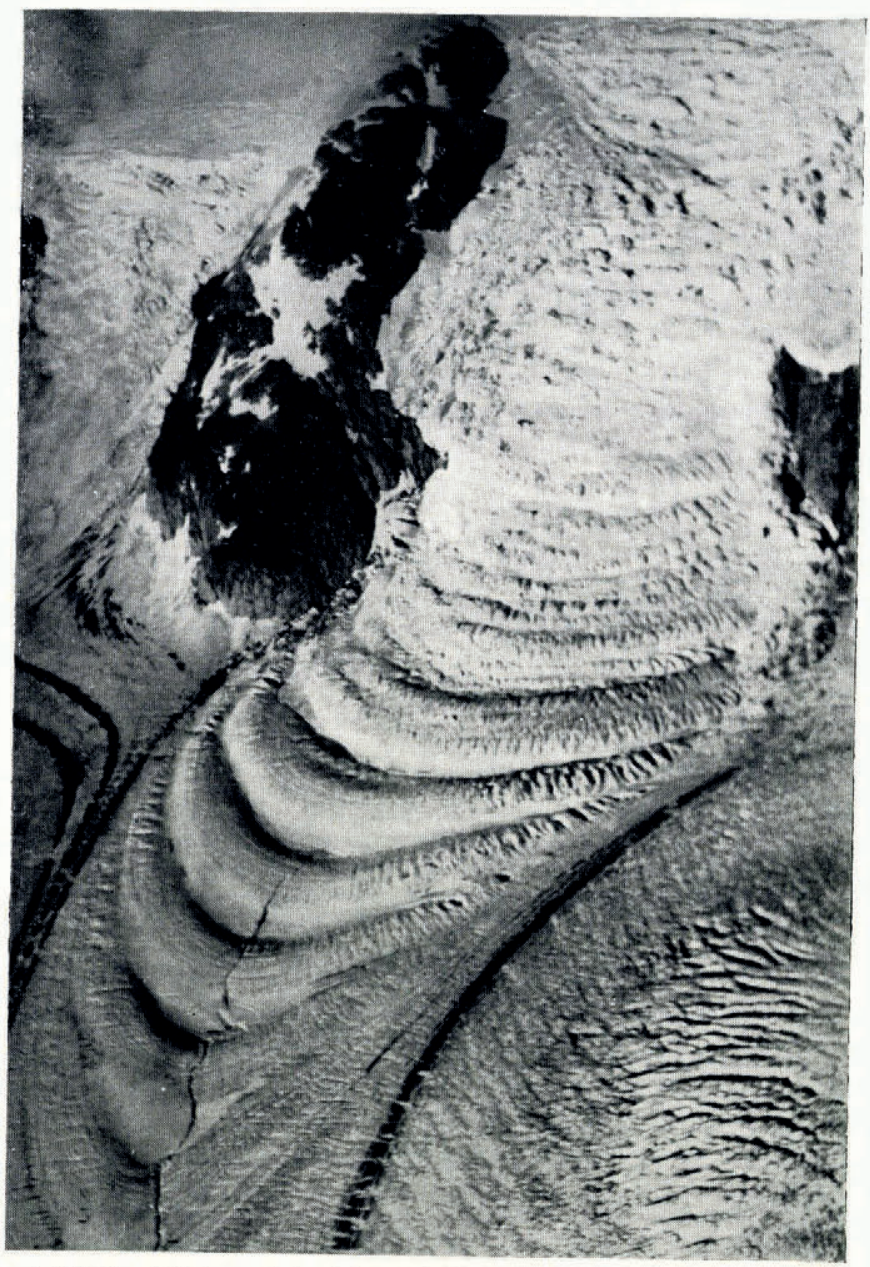

Fig. 2. The Vaughan Lewis Glacier. (Photograph by Maynard M. Miller; reproduced by courlesy of the Editor of Geotimes)

Between I 958 and I96 I a group of eight buildings was erected at the 7,00o ft. (2,I 34 m.) level, near this glacier, to serve as the headquarters of the Glaciological Institute. Since W. Vaughan Lewis was to have been the first Visiting Professor of the Glaciological Institute and working in the Juneau Icefield, it is most fitting that this glacier has been named after him.

The Board on Geographic Names, United States Department of the Interior, has approved for Federal use the place-name Vaughan Lewis Glacier, which has been published in Decision List 6203.

(From information provided by Dr. Maynard M. Miller.) 